\title{
INTERVENSI MILITER TERHADAP KUDETA POLITIK MENURUT PRINSIP J US COGENS
}

\author{
Sandy Kurnia Christmas ${ }^{1 *}$, J oko Setiyono ${ }^{2}$ \\ 1Fakultas Hukum, Universitas Tanjungpura \\ 2Program Studi Magister Ilmu Hukum, Fakultas Hukum, Universitas Diponegoro \\ ch.sandykurnia@gmail.com
}

\begin{abstract}
Military intervention is an act of interference by a country that is realized by sending a military expedition to support a government or rebel group. Whether the intervention can be justified in international law and whether the coup in a military intervention can be carried out according to the principle of J us Cogens is something that will be discussed in this study. This article aims to examine whether military intervention in the case of the United States against Venezuela in 2019 with the aim of a political coup. The research method in this study is doctrinal research, through conseptual approach and case approach. The results of this study conclude that: the first military intervention is something that is prohibited under Article 2.4 of the UN Charter, but if in a state of threat to international peace, military intervention can be carried out within the limits given by the UN Security Council in accordance with Article 39 United Nations Charter. Secondly, in the event of the threat of a coup d'etat affecting state sovereignty, military intervention is a violation according to J us Cogens' principle as an international legal norm. This concerns each country must respect each other's sovereignty.
\end{abstract}

\section{Keywords: Mlitary Intenvention; Intemetional Lam; Coup; J us Cogens.}

\begin{abstract}
ABSTRAK
Intervensi Militer merupakan tindakan campur tangan suatu negara yang diwujudkan dengan mengirimkan ekspedisi militer untuk menunjang suatu pemerintahan atau kelompok pemberontak, dimana hal ini tidak dapat dibenarkan menurut hukum internasional maupun didalam prinsip J us Cogens. Tulisan ini bertujuan untuk mengkaji tindakan intervensi militer yang dilakukan Amerika Serikat terhadap Venezuela di tahun 2019 dengan maksud melakukan kudeta politik. Metode penelitian dalam penelitian ini adalah penelitian doktrinal, melalui conseptual approach dan case approach. Hasil penelitian yaitu : pertama tindakan intervensi militer merupakan sesuatu yang dilarang berdasarkan Pasal 2 ayat (4) Piagam PBB, namun jika dalam keadaan ancaman terhadap perdamaian internasional maka tindakan intervensi militer dapat dilakukan dalam batasan yang diberikan oleh Dewan Keamanan PBB sesuai Pasal 39 Piagam PBB. Kedua, dalam keadaan ancaman tindakan kudeta yang mempengaruhi kedaulatan negara, tindakan intervensi militer merupakan suatu pelanggaran menurut prinsip J us Cogens sebagai norma hukum internasional dimana setiap negara harus saling menghormati kedaulatan suatu negara.
\end{abstract}

\section{Kata Kunci : Intervensi Militer; Hukum Internasional; Kudeta; J us Cogens.}

\footnotetext{
${ }^{*}$ Corresponding Author
} 
Jurnal Pembangunan Hukum Indonesia

Volume 1, Nomor 3, Tahun 2019
Program Studi Magister Ilmu Hukum Fakultas Hukum Universitas Diponegoro

\section{A. PENDAHULUAN}

Politik, hukum, dan militer merupakan suatu objek kajian yang menggambarkan konstelasi keadaan di suatu negara dalam memenuhi kepentingan dan tujuan negara. Tidak jarang dallam mewujudkan kepentingan dan tujaun negara sering kali terjadi pertentangan atau konflik, dimana kondlik ini dapat dipicu oleh beberapa faktor, seperti konflik internal politik, krisis politik, serta keuangan negara dab beberapa perbedaan pandangan ideologi. Dalam hubungan poltik, hukum, dan militer sering kali dikaitkan dengan kewajiban mempertahankan keamanan dan kedaulatan negara dimana kewajiban negara adalah melindungi rakyat didalam negaranya (Hendra, 2014). Konflik dalam batasan internasional terkadang muncul karena adanya keberpihakan atas dasar kerjasama yang mendasar dan bermanfaat (Yuniasih, Rizky, \& Natasha, 2016), dan sering kali konflik yang sering berakibat destruktif ini mengganggu keamanan dan ketertiban suatu negara. Adapun ancaman konflik seperti intervensi militer ini berdampak pada tindakan kudeta politik.

Intervensi militer dalam hal ini didefinisikan sebagai penggunaan kekuatan lintas batas negara dengan ukuran-ukuran keadilan dan alasan-alasan bagi aksi mereka dengan mengirimkan ekspedisi militer yang, dimana alasan yang mereka gunakan berkaitan dengan menciptakan perdamaian serta keamanan dunia yang dalam kaitan nya untuk menghentikan terjadinya pelanggaran terhadap HAM. Dalam hal ini intervensi militer dianggap merupakan bagian dari solusi untuk menghentikan perang internal. Dalam kebijakan politik luar negeri suatu negara menjelaskan bahwa untuk keputusan intervensi militer dipengaruhi oleh konsiderasi domestik dan internasional (Murtadlo, 2014)

Pada kasus yang terjadi di Venezuela ini berawal ketika permasalahan krisis sosial-ekonomi sehingga memicu hiperinflasi yang berdampak pada runtuhnya perekonomian di Venezuela. Runtuhnya perekonomian ini menyebabkan kemiskinan sampai kepada migrasi secara besar-besaran oleh penduduknya. Dalam hal ini, intervensi militer yang dilakukan Amerika Serikat terhadap Venezuela di tahun 2019, bermaksud untuk mendukung pemimpin sementara Juan Guaido dalam upaya melakukan kudeta politik untuk melengserkan kepemimpinan Nicolas Maduro sebagai Presiden Terpilih yang dilantik pada Januari 2019. Kudeta dalam hal ini sebagai kunci untuk dapat mengambil alih kekuasaan berdasarkan pada memburuknya situasi suatu negara. Kudeta yang dilakukan oleh Juan Guaido mengalami kegagalan, sehingga memaksa pihak Amerika Serikat campur tangan dalam urusan intervensi militernya.

Dalam hukum internasional, tindakan intervensi militer dalam upaya kudeta dilarang karena dianggap tindakan yang terlalu mencampuri urusan dalam negeri dan mengancam kedaulatan suatu negara. Menurut Federica Mogherini selaku Kepala Kebijakan Luar Negeri Uni Eropa menyatakan ketegangan yang meningkat drastis di Venezuela harus diselesaikan dengan solusi yang bersifat mementingkan sisi politis yang damai serta 
demokratis, dimana tindakan intervensi ini tidak dapat diterima sebagai solusi yang baik untuk meredakan konflik internal Venezuela. Sehingga tidak boleh ada paksaan intervensi dari luar. (Nursalikah, 2019b)

Pasal 2 ayat (4) Piagam PBB (Charter of The United Nations and Statute of The International Court of J ustice) berbunyi, "Segenap anggota dalam hubungan internasional mereka, menjauhkan diri dari tindakan mengancam atau menggunakan kekerasan terhadap integritas wilayah atau kemerdekaan politik sesuatu negara lain atau dengan cara apapun yang bertentangan dengan tujuan-tujuan Perserikatan Bangsa-Bangsa." Hal ini kemudian dijelaskan melalui Prinsip Non-Intervensi yaitu Peremptory Norm atau Norma Dasar (J us Cogens). Dalam pandangan J us Cogens, menurut Brownlie menyatakan "Norma Dasar didalam J us Cogens merupakan norma yang tidak boleh dilalaikan maupun dikesampingkan dalam penerapannya di dalam hukum internasional, meski dalam keadaan apapun tanpa terkecuali."

Pada prinsipnya J us Cogens disebut sebagai kaidah yang membatasi kehendak negara, dalam kasus ini yaitu kebijakan intervensi militer yang dikeluarkan Amerika Serikat. Kaidah-kaidah tersebut dalam lingkup kaidah hukum yang mengancam, yang termanifestasikan didalam Pasal 53 Konvensi Wina 1969 (Vienna Convention on the Law of Treaties 1969).

Melihat permasalahan tersebut dalam pemahamannya mengenai intervensi miiter yang dilakukan Amerika Serikat dalam upaya kudeta politik
Venezuela, maka permasalahan dalam tulisan ini adalah apakah tindakan intervensi militer Amerika Serikat dalam upaya kudeta politik dapat dibenarkan didalam prinsip J us Cogens humum internasional ?

Pada penelitian sebelumnya terkait intervensi militer dalam tinjauan prinsip Jus Cogens belum pernah dilakukan. Penelitian oleh Emi Eliza dkk membahas mengenai intervensi kemanusiaan dalam tinjauan implementasinya didalam konflik bersenjata (Eliza, Heryandi, \& Syofyan, 2014). Pada penelitian oleh Husnul Murtadlo membahas mengenai intervensi militer dalam sekularisme dan fundamentalisme islam (Murtadlo, 2014). Penelitian oleh Khudzaifah Dimyati, dkk membahas mengenai intervensi kekuasaan dalam radikalisme islam dan peradilan (Dimyati, Muqoddas, \& Wardiono, 2013). Penelitian oleh Joko Priyono membahas mengenai intervensi kemanusiaan dalam perspektif pemikiran kosmopolit (Priyono, 2011). Penelitian oleh Mohamad Rosyidin membahas intervensi dalam perdebatan realis dan konstruktivis (Rosyidin, 2016). Sedangkan dalam penelitian Adinda Nanda Saraswati hanya membahas Prinsip J us Cogens dalam perspektif hak asasi manusia (Saraswati, 2017). Adapun didalam penelitian jurnal internasional oleh Kenneth Roth membahas dalam kaitan perang dan intervensi kemanusiaan (Roth, 2006). Sedangkan penelitian oleh Anythony T. Eniayejuni hanya membahas mengenai peran intervensi militer di Libya (Eniayejuni, 2012). 


\section{B. METODE PENELITIAN}

Pembahasan mengenai intervensi militer terhadap kudeta pilitik ini diteliti dengan menggunakan kajian dalam pendekatan hukum doktrinal dalam penerapannya di kaidah dan norma hukum, dimana penelitian ini dikaji dalam Pendekatan Konseptual (Conseptual Approach) dan Pendekatan Studi Kasus (Case Approach).

Pada penelitian hukum doktrinal ini, digunakan data sekunder sebagai kekuatan mengikat didalamnya yang terdiri dari bahan hukum primer yang mengikat seperti Piagam PBB (Charter of The United Nations and Statute of The International Court of J ustice 1945), Deklarasi Universal Hak Asasi Manusia (Universal Declaration of Human Rights 1948, Konvenan Hak Sipil dan Politik (International Convenant on Civil and Political Rights 1976) serta Vienna Convention on the Law of Treaties between States and International Organizations or between International Organizations 1986. Serta dikaji menggunakan bahan hukum sekunder di dalam buku-buku, artikel, jurnal, serta makalah yang relevan dalam penelitian ini.

\section{HASIL DAN PEMBAHASAN}

\section{Kasus Intervensi Militer Amerika Serikat Terhadap Venezuela Tahun 2019}

Krisis Venezuela pada tahun 2019 berlatar belakang dari adanya krisis sosial-ekonomi sejak tahun 2010 di bawah kepemimpinan Nicolas Maduro, dimana akibat dari dari krisis ini adalah meningkatnya kriminalitas, hiperinflasi, serta menurunnya kualitas hidup di Venzuela. Krisis ini ditambah dengan adanya krisis kepemimpinan pasca pemilu pada tahun 2019 dimana terdapat perselisihan dua kepemimpinan Venezuela oleh Nicolas Maduro dan Juan Guaido dimana pemilu dimenangkan oleh Nicolas Maduro, sedangkan Juan Guaido yang banyak didukung oleh rakyat Venezuela menganggap hasil pemilihan tidak sah (Aninda, 2019).

Dukungan terhadap Juan Guaido sebagai oposisi tidak hanya oleh sebagian besar rakyat Venezuela, tetapi oleh beberapa negara seperti Amerika Serikat, Brazil, Chile, Kanada, Inggris, Jerman, Spanyol, Australia, dan Israel. Sedangkan Maduro didukung oleh Rusia, Tiongkok, Turki, Bolivia, dan Meksiko (Aipassa, 2019).

Adanya dukungan Amerika Serikat terhadap Juan Guaido inilah merupakan cikal bakal adanya tindakan intervensi oleh Amerika Serikat dengan mengirimkan pasukan militer ke Venezuela sebagai bentuk penekanan untuk menggulingkan Presiden Nicolas Maduro. Tindakan intervensi militer oleh Amerika Serikat yang dipimpin oleh Presiden Donald Trump ini penekanan terhadap Maduro karena seharusnya Venezuela mengegakkan konstitusi dengan melindungi rakyat dari adanya krisis-krisis yang terjadi (Nursalikah, 2019a).

Tindakan Amerika Serikat dalam melancarkan intervensi militer ini menuai pro dan kontra. Dukungan terhadap intervensi ini beralasan karena seharusnya dunia internasional melihat tindakan intervensi ini sebagai tindakan kemanusiaan karena 
berusaha membantu suatu negara dari adanya krisiskrisis yang terjadi di negara tersebut. Sedangkan kritik terhadap tindakan intervensi ini karena dinilai mengganggu urusan dalam negeri suatu negara dan kedaulatan negara tersebut. Bahkan menurut Uni Eropa menilai intervensi militer di Venezuela bukanlah jalan terbaik dalam menyelesaikan krisis kemanusiaan dan politik. Karena pada dasarknya solusi terbaik haruslah bersifat politis yang damai dan demokratis (Nursalikah, 2019b).

\section{Pengaturan Intervensi Militer menurut Hukum Internasional dalam Piagam PBB (Charter of United Nations 1945)}

Intervensi adalah salah satu tindakan mencampuri urusan internal suatu negara yang bermaksud untuk memelihara serta mengubah situasi politik yang sedang berlangsung (Eliza, Heryandi, \& Syofyan, 2014). Dalam pemikiran yang dikemukakan oleh J.G. Starke mengenai intervensi yaitu "Intervensi sering diwujudkan dalam bentuk propaganda serta tindakan lainnya yang memicu timbulnya suaru revolusi atau perang saudara." Mengacu pada permasalahan dalam penelitian ini, intervensi dibagi kedalam enam bentuk menurut Kalevi J. Holsti, salah satu bentuk intervensi adalah Intervensi Militer.

Intervensi Militer menurut Kalevi J. Holsti dimaknai sebagai "Bentuk campur tangan yang diwujudkan dengan cara mengirimkan ekspedisi militer untuk menunjang suatu pemerintahan yang sedang berkuasa ataupun membantu kelompok pemberontak." Dalam kasus ini, tindakan yang dikeluarkan Amerika Serikat dalam kebijakan intervensi militer yaitu dalam upaya membantu pihak oposisi (Juan Guaido) dalam upaya kudeta melengserkan kedudukan Presiden Maduro.

Dalam melakukan suatu tindakan intervensi, dimana dalam kajian ini mengenai intervensi militer pada hakikatnya belum ada pengaturan resmi mengenai tindakan ini. Pasal 2 ayat (4) Piagam PBB (Charter of the United Nations 1945), menyatakan bahwa, "Seluruh negara anggota dalam hubungan internasional, menjauhkan diri dari tindakan yang mengancam atau menggunakan kekerasan terhadap integritas wilayah atau kemerdekaan politik sesuatu negara lain dengan cara apapun yang bertentangan dengan tujuan-tujuan Perserikatan Bangsa-Bangsa." Dalam hal ini berdasarkan Pasal 2 ayat (7) Piagam PBB menyatakan bahwa, "tidak ada satupun ketentuan dalam Piagam PBB yang memberikan kuasa kepada PBB untuk mencampuri urusan-urusan (intervensi) yang pada hakekatnya termasuk urusan dalam negeri suatu negara." Intervensi militer tidak boleh dianggap enteng, bahkan untuk tujuan kemanusiaan, karena kematian, kehancuran, dan kekacauan adalah konsekuensi yang dapat diprediksi dari sebagian besar perang (Roth, 2006).

Pemaknaan mengenai adanya tindakan intervensi ini dikarenakan adanya suatu yang dianggap kejahatan yang dilakukan oleh negara itu, sehingga menyebabkan negara dan otoritasnya mengalami kelumpuhan atau dalam keadaan tidak mampu untuk mengendalikan hal tersebut, sehingga 
Jurnal Pembangunan Hukum Indonesia

Volume 1, Nomor 3, Tahun 2019
Program Studi Magister Ilmu Hukum Fakultas Hukum Universitas Diponegoro datannya negara lain memiliki makna dari adanya campur tangan suatu negara didalam intervensi (Erliyana, 2006).

Dalam Hukum Internasional setidaknya mengklasifikasikan 3 (tiga) jenis intervensi berdasarkan jangkauannya, yaitu (Starke, 2012) : (1) Intervensi Internal (Internal Intervention), yaitu tindakan mencampuri urusan dalam negeri suatu negara dengan melibatkan negara luar sebagai pendukung dalam suatu pemberontak, peperangan, atau konflik politik di negara lain dengan cara diktator; (2) Intervensi Eksternal (Eksternal Intervention), yaitu tindakan mencampuri urusan dalam negeri suatu negara yang terlibat dalam peperangan atau konflik antar negara; dan (3) Intervensi Reprasial / Penghukuman (Purnitive Intervention), yaitu tindakan mencampuri urusan dalam negeri suatu negara, dimana bermaksud untuk melakukan atas dasar pembalasan (reprasial) terhadap kerugian yang telah ditimbulkan oleh negara lain, dengan melakukan perang kecil atau blokade damai.

Tindakan intervensi militer yang dilakukan Amerika Serikat termasuk dalam kategori intervensi internal, karena merupakan suatu intervensi yang ikut dalam campur tangan urusan dalam negeri Venezuela, disisi lain, tindakan tersebut sebagai dukungan terhadap pemimpin oposisi Juan Guaido. Timbulnya tindakan intervensi yang dilakukan Amerika Serikat ini membuat persepsi bahwa tindakan intervensi sering dilakukan oleh untuk menekan kebebasan serta kemerdekaan negara lemah dari negara kuat, sehingga kedaulatan suatu negara terguncang (Putri, 2015).

Intervensi pada dasarnya merupakan instrumen kebijakan luar negeri yang menekankan pada persoalan diplomatik, negosiasi, dan perang. Dalam kasusnya, tindakan intervensi militer yang dikeluarkan Amerika Serikat ini dikategorikan sebagai kebijakan, dimana menurut Blakemore, kebijakan ini dimaksud sebagai suatu rangkaian konsep dalam pedoman merencanakan suatu implementasi dalam cara bertindak kepemimpinannya. Hal serupa juga dikaitkan menurut pendapat Sir William Harcourt dimana menyatakan bahwa, "Intervensi merupakan suatu masalah yang lebih dekat kaitannya dengan kebijakan dibandingkan dengan hukum. Intervensi berada jauh diatas dan di luar jangkauan hukum (bila dilaksanakan oleh pihak yang memiliki kekuasaan dimaksudkan untuk mendapat pengaruh daripadanya) dan merupakan kebijakan tingkat tinggi yang berkaitan dengan keadilan dan kemanusiaan. Hal yang membedakannya hanyalah permasalahan tujuannya, sedangkan caranya tetap sama yaitu dengan instrumen militer (Rosyidin, 2016).

Konflik yang terjadi di Venezuela menjadi persoalan yang besar ketika adanya upaya intervensi militer Amerika Serikat. Dalam hal ini, Pemerintah Rusia mengecam campur tangan negara luar (khususnya AS) dalam kasus yang terjadi di Venezuela. Hal ini kemudian Kementerian Luar Negeri Rusia melalui Jubir Rusia, Kremlin Dmitry Peskov memperingatkan dukungan internasional terhadap pemimpin oposisi Juan Guaido) sebagai 
presiden sementara adalah suatu bentuk yang penting terhadap konflik dalam negeri yaitu pelanggaran terhadap dasar-dasar hukum Pasal 2 ayat (7) Piagam PBB berbunyi tidak ada internasional (Sukarno, 2019). Karena hal ini dapat kuasa kepada PBB dalam melakukan intervensi memicu terhadap ancaman terhadap perdamaian dan persoalan keberpihakan.

Pada tataran ini, tindakan intervensi militer dalam kudeta politik dapat menjadi ancaman, karena hal ini tidak ada hubungannya dengan demokrasi yang terjadi didalam negara tersebut. Tindakan intervensi militer dalam hukum internasional dapat menjadi ancaman kekerasan apabila suatu negara menjalankan suatu tindakan yang melanggar dan mengancam perdamaian dalam melakukan agresi terhadap negara lain; apabila suatu negara melakukan tindak provokasi yang mengancam keamanan negara lainnya; dan apabila terdapat masuk atau hadirnya pasukan militer asing ke suatu negara melalui atau tanpa perjanjian internasional yang tidak dapat dibenarkan didalam Piagam PBB maupun hukum internasional (Suryokusumo, 2003).

Perumusan Pasal 1 ayat (1) Piagam PBB menyatakan mengenai kewajiban negara-negara dalam upaya memelihara perdamaian dan keamanan internasional sebagai tujuan semua negara. Hal ini juga dalam tindakan melakukan upaya-upaya yang efektif dalam mencegah terjadinya ancamanancaman terhadap pelanggaran-pelanggaran dalam mewujudkan perdamaian. Yang kemudian dalam upaya menyelesaikan persoalan atau konflik dalam negeri, suatu negara harus menyelesaian persengketaan itu dengan jalan damai sesuai dengan ketentuan Pasal 2 ayat (3) Piagam PBB. Dan hal lain termasuk urusan dalam negeri, kecuali tindakantindakan pemaksaan yang tercantum dalam Bab VII yang berkaitan dengan perdamaian internasional.

Hal ini menjadi jelas didalam Pasal 2 ayat (4) Piagam PBB dalam hubungan internasional menjauhkan diri dari tindakan yang mengancam kekerasan yang dilarang. Pada pemahamanannya tindakan intervensi militer dilarang dalam hukum internasional jika : (1) Merusak integritas wilayah suatu negara (impairs the territorial integrity of the state); (2) mempengaruhi independensi politik (affects its political independence); dan (3) Bertentangan dengan tujuan Perserikatan BangsaBangsa (Contrary to the objective of the United Nations).

Dalam tipologi dari pola intervensi tersebut, menurut J.G. Starke tindakan intervensi dapat menjadi suatu tindakan legal yang dalam hal ini dapat dibenarkan menurut hukum internasional. Pembenaran terhadap adanya tindakan intervensi militer ini jika hal tersebut bertentangan dengan tujuan PBB dalam memelihara keamanan dan perdamaian dunia terhadap adanya tindakan agresi. Berdasarkan Bab VII Piagam PBB tindakan intervensi dapat dibenarkan dalam batasan yang diputuskan dan ditentukan oleh PBB. Pada Pasal 37 Piagam PBB menetapkan tindakan intervensi militer dapat diambil jika membahayakan pemeliharaan perdamaian dan keamanan internasional. Dan dalam 
Jurnal Pembangunan Hukum Indonesia

Volume 1, Nomor 3, Tahun 2019
Program Studi Magister Ilmu Hukum

Fakultas Hukum Universitas Diponegoro
Pasal 51 Piagam PBB hanya mengijinkan penggunaan militer dalam rangka membela diri apabila suatu negara telah benar-benar diserang (Latifulhayat, 2004). Tindakan intervensi militer tersebut hanya dapat dibenarkan dalam kondisi yaitu

: (1) Intervensi Kolektif atau secara bersama, yang ditentukan dalam Piagam PBB (Pasal 39 Piagam PBB); (2) Intervensi yang bermaksud melindungi hak dan kepentingan, serta keselamatan warga negaranya di negara lain; (3) Pembelaan Diri / SelfDefence (Pasal 51 Piagam PBB); (4) Intervensi dalam hubungannya dengan negara protektorat atas dominionnya; serta (5) Jika negara yang akan diintervensi dianggapp telah melakukan pelanggaran berat atas hukum internasional.

Didalam pendekatan Ex-Ante mendasarkan pada "right intention" atau "good intention" menyatakan kesulitannya dalam memperkirakan tindakan dan maksud intervensi yang dilakukan suatu negara. Jika berbicara mengenai takaran yang positif, tindakan campur tangan ini bermaksuda menciptakan keamanan dan perdamaian dunia, memberikan bantuan terhadap hak asasi dan keadilan, seta untuk mengurangi terjadinya pelanggaran hak asasi atas penderitaan manusia. Hal ini berbanding terbalik jika kegiatan campur tangan intervensi ini dimaksudkan untik kepentingan pribadi manupun politik (Priyono, 2011). Sehingga dalam hal ini sulit untuk mengukur tindakan intervensi dalam tujuan-tujuan kepentingannya.

Sejatinya didalam hukum internasional, intervensi yang dilakukan suatu negara merupakan suatu tindakan yang melanggar kaidah hukum internasional yang terlalu mengurusui urusan internal negara lain. Karena dalam tataran berbicara mengenai urusan suatu negara, berarti juga berbicara mengenai kedaulatan negara tersebut. Kedaulatan negara menurut pandangan ini tidak terbatas pada kekuasaan untuk menguasai suatu wilayah tertentu dari invasi luar, tetapi juga lebih jauh kedaulatan ini mengarahkan hak negara untuk secara bebas menentukan status politik, struktur sosial, ekonomi, dan budaya dalam wilayah tersebut tanpa campur tangan negara lain.

\section{Prinsip Non-Intervensi dalam Pengertian Jus Cogens sebagai Dasar Hukum Internasional}

Isu intervensi pada hakikatnya selalu berkaitan dengan perdebatan dalam konsep kedaulatan. Berbicara mengenai doktrin intervensi, indikasi terhadap tindakan intervensi sangatlah kontradiktif dalam makna hukum internasional. Hal ini karena dokrtin mengenai intervensi ini tidak selaras dengan prinsip dasar hukum internasional mengenai "Prinsip Non-Intervensi". Dalam hal ini, Prinsip Non-Intervensi digambarkan sebagai prinsip dasar hukum internasional yang berhubungan erat dengan hal tersebut adalah melalui Prinsip Kedaulatan Negara. Jika berbicara mengenai kedaulatan negara, hal ini telah muncul sejak lahirnya perjanjian Westphalia Tahun 1648 (The Treaty of Westphalia 1648). Negara memiliki kedaulatan penuh dalam dasar kemerdekaan dan persamaan derajat (freedom and equality), artinya bahwa setiap negara berdaulat 
Jurnal Pembangunan Hukum Indonesia

Volume 1, Nomor 3, Tahun 2019
Program Studi Magister Ilmu Hukum Fakultas Hukum Universitas Diponegoro bebas dari penekanan, intimidasi, maupun intervensi dari negara lain. Dimana negara-negara berdaulat wajib menjaga harmonisasinya dengan negara lain dengan tidak mengurusi urusan internal suatu negara dalam kaitan relasi antar negara. Argumentasinya bahwa kedaulatan tidak bersifat tak terbatas, karena persoalan ini lebih menyentuh aspek filosofis dibanding politis, sedangkan dalam tataran lain kedaulatan.

Prinsip Non-Intervensi dalam hal ini termasuk dalam tahap Peremptory Norm (J us Cogens). Dalam konteks hukum internasional, "J us Cogens" diartikan sebagai norma yang memiliki karaktek paksaan serta yang wajib dilaksanakan semua negara karena statusnya berkedudukan tinggi didalam norma hukum internasional (Saraswati, 2017). Dimana menurut pemikiran Ian Brownlie menyatakan, "Norma Hukum internasional yang memiliki status J us Cogens tidak dapat diabaikan dalam situasi apapun." Menurut Sir Humprey Waldock di dalam "Second Report on the Law of Treaties" menerangkan makna Jus Cogens sebagai norma umum hukum internasional yang harus ditaati atau tidak boleh dilanggar, di mana derogasi tidak diizinkan kecuali derogasi tersebut didasarkan pada hukum internasional yang umum, dan norma tersebut hanya dapat dimodifikasi atau digantikan oleh norma lain yang juga merupakan hukum internasional yang umum.

Seperti yang tercantum didalam Pasal 53 Konvensi Wina 1986 (Vienna Convention on the Law of Treaties between States and International Organizations or Between International Organizations
1986), J us Cogens didefinisikan sebagai Peremptory Norm / Norma Dasar dari hukum internasional umum yang diterima dan diakui oleh masyarakat internasional secara keseluruhan sebagai norma dari penghinaan yang tidak diperbolehkan dan yang dapat dimodifikasi hanya oleh norma hukum internasional yang memiliki karakter yang sama.

Dalam upaya pencegahan terhadap tindak intervensi, terdapat deklarasi yang dibuat Majelis Umum PBB tentang tentang Declaration on the Inadmissibility of Intervention in the Domestic Affairs of States and the Protection of their Independence and Sovereignty (G.A. Res. 2131/XX, 21 Desember 1965), dalam paragraf pertama yang menyatakan bahwa setiap negara tidak memiliki hak untuk melakukan intervensi, langsung maupun tidak langsung, untuk alasan apapun, didalam urusan dalam maupun luar negeri sebuah negara. Meskipun begitu, dalam identifikasi suatu ketentuan berkenaaan dengan J us Cogens, prinsip ini ternyata memiliki dilematika dalam pendefinisian terhadap bentuk norma dan aspek substantifnya. Didalam Konvensi Wina tidak memberikan daftar terhadap kategori J us Cogens. Dalam hal ini terdapat 5 (lima) kriteria substantif dalam hubungan struktur dan isi, yaitu: (1) Integrity, yaitu J us Cogens yang berprinsip intergritas, dimana harus mempunyai tujuan yang mendatangkan kebaikan untuk masyarakat; (2) Principle of Formal Moral Equality, yaitu norma keadilan terhadap kesetaraan yang dimaknai sebagai "fainess"; (3) Principle of Solictude, yaitu norma dasar yang harus melihat kepada kepentingan subjek 
hukum yang sah; (4) Principle of Fundamental Equal Security, yaitu norma yang memiliki esensi didalam kesetaraan dan keamanan fundamenyal, dimana negara tidak boleh melanggar norma hukum yang telah ditetapkan. Prinsip inilah yang menggambarkan derogable dan non-derogable; dan (5) Rule of Law, yaitu aturan terhadap legalitas jaminan hukum untuk kepentingan bersama, dimana memiliki arti bahwa suatu tindakan negara harus didasarin pada dasar hukum yang berlaku (Criddle, \& Decent, 2009).

Pada tataran ini, prinsip non-intervensi dan J us Cogens menjadi satu bagian yang tak terpisahkan bila berbicara dalam kepentingan mewujudkan perdamaian. Walaupun dalam tataran integritas, pemaknaan mengenai "untuk ketertiban masyarakat dunia" menjadi persoalnya yang rumit bila mana menunjuk pada masyarakat. Menurut Hedley Bull, mengatakan bahwa negara-negara tidak memiliki hak dalam melakukan intervensi yang mengancam kedaulatan suatu negara karena melanggar prinsip non-intervensi (Indrawan, 2013). Dan kemudian hal ini harus memperhatikan Principle of Solictude pentingan subjek hukum yang sah dimana kasus ini merupakan Venezuela.

Pada kasus ini, tindakan Amerika Serikat dalam melakukan tindakan intervensi ini bukan hanya dalam rangka bantuan kemanusiaan, melainkan lebih darii pada kepentingan politik dimana tindakan intervensi ini disertai dengan kudeta politik terhadap Presiden terpilih Venezuela Nicolas Maduro. Menurut Eric. A Nordlinger menaruh perhatian tindakan kudeta sebagai Proses Politik atau Political Process yaitu "Tindakan yang mengarah pada upaya suatu negara dalam mencapai akses terhadap kekuasaan politik dalam mencapai kepentingannya." Pengaruh politik ini kemudian menggunakan militer sebagai penggeraknya dimana tindakan penggunaan militer sebagai upaya intervensi memiliki kemampuan koersifnya (paksaan) untuk mencapai kepentingan negaranya atau State Interests (Zainal, 2013).

Dalam hal ini, kudeta merupakan sebuah kunci bagi seorang perwira militer untuk dapat mengambil kekuasaan negara. Hal ini biasanya dilakukan berdasarkan keadaan negara yang situasinya memburuk dari sisi ekonomi dan politik, misalnya korupsi oleh pejabat negara, aktor-aktor separatisme, kenaikan tingkat inflasi, tingkat pengangguran yang naik, dan lain-lain. Mayoritas sebagian kudeta atau seluruhnya termotivasi oleh pertahanan atau pemberlakuan kepentingan korporasi militer (Acemoglu, Ticchi, \& Vindigni, 2010). Menurut Spawforth Hornblower dalam The Oxford Companion to Classical Civilization mendefinisikan tindakan kudeta selalu dihubungkan dengan menjatuhkan suatu letigimasi suatu negara terhadap kekuasaan dengan cara-cara yang ilegal serta inkonstitusional dalam upaya menggulingkan serta mengambil alih paksa kekuasaan yang sedang berlangsung (Setiawan, 20015). Mayoritas sebagian kudeta atau seluruhnya termotivasi oleh pertahanan atau pemberlakuan kepentingan korporasi militer (Acemoglu, Ticchi, \& Vindigni, 2010).

Dalam pemahaman konteks mengenai Jus Cogens menjadi sebuah dilematika dalam prinsip- 
Jurnal Pembangunan Hukum Indonesia

Volume 1, Nomor 3, Tahun 2019
Program Studi Magister Ilmu Hukum Fakultas Hukum Universitas Diponegoro prinsipnya. Menurut pendapat Schwarzerberger dibutuhkan suatu aturan hukum internasional yang memperhatikan aspek kepentingan umum didalam asas-asas fundamental dalam membentuk Jus Cogens. Asas-asas tersebut kemudian menjadi bagian yang esensial dalam sistem hukum internasional, apabila hal tersebut diterapkan, maka akan menimbulkan tujuan baru didalam asas tersebut, seperti : kedaulatan, pengakuan, itikad baik, hak membela diri, serta tanggung jawab internasional. Dalam hal ini terdapat 3 (tiga) prinsip atau aturan yang dapat menjadi J us Cogens didalam hukum internasional, yaitu : (1) Kepentingan bersama dalam masyarakat internasional; (2) Adanya tujuantujuan kemanusiaan; dan (3) Sesuai dengan prinsip dan tujuan didalam Piagam PBB.

Dalam kasus Venezuela dan Amerika Serikat, tindakan intervensi Amerika Serikat dapat dibenarkan jika dalam pembatasan tindakan didalam ketentuan Pasal 2 ayat (4) Piagam PBB. Legalitas terhadap tindakan intervensi haruslah dihubungkan dengan tujuan PBB dalam menghormati hak asasi manusia berdasarkan Pasal 1 ayat (3) Piagam PBB. Adanya pembatasan ini diharapkan untuk membatasi tindakan sewenang-wenang negara. Sehingga jika dilakukan pada tataran intervensi terhadap kudeta negara menyangkut persoalan kedaulatan suatu negara, yang dalam kejadiannya Venezuela sedang dilanda krisis ekonomi sehingga menyebabkan keguncangan pada sektor ekonomi dan politik negara, dimana kemudian hal ini sangat dilarang yang secara kontekstual didalam Pasal 1 ayat (1)
Kovenan Hak Sipil dan Politik yang menyatakan semua bangsa berhak menentukan nasibnya sendiri, baik dalam status politik maupun ekonomi.

Dalam tataran J us Cogens terkait pelanggaran dalam intervensi terhadap kudeta politik, mendalilkan tindakan ini pelanggaran prinsip kedaulatan (principle of permanent sovereignty). Karena pada prinsipnya, pembelaan diri terhadap negara demi mempertahankan kedaulatan dan kemerdekaan mereka adalah termasuk norma Jus Cogens (Muhammadin, 2018). Prinsip Non-Intervensi melibatkan hak setiap negara berdaulat untuk melakukan urusan tanpa campur tangan dari luar. Pada prinsipnya, diantara negara yang merdeka harus saling menghormati kedaulatan teritorial sebagai pondasi didalam hubungan internasional dan hukum internasional dimana diperlukan integritas politik.

\section{SIMPULAN}

Instrumen hukum internasional Piagam PBB menyebutkan bahwa tindakan intervensi merupakan tindakan yang dilarang karena bertentangan dengan prinsip hukum internasional dalam menjaga keamanan dan perdamaian dunia. Namun pada tataran intervensi kolektif, dalam otoritas Dewan Keamanan PBB, hal ini dapat saja dilakukan jika tidak bertentangan pada peraturan didalam Pasal 2 ayat (4) Piagam PBB. Pada dasarnya, prinsip J us Cogens didalam norma hukum internasional yang bersifat memaksa, menetapkan bahwa tindakan intervensi merupakan tindakan yang bertentangan 
Jurnal Pembangunan Hukum Indonesia

Volume 1, Nomor 3, Tahun 2019
Program Studi Magister Ilmu Hukum Fakultas Hukum Universitas Diponegoro dan dilarang didalam hukum internasional dan hubungan internasional dalam tindakan pelanggaran kedaulatan negara. Karena dianggap mencampuri urusan dalam negeri suatu negara dan bertentangan dengan Pasal 1 ayat (1) Konvenan Hak Sipil dan Politik. Tindakan intervensi militer yang dilakukan Amerika Serikat terhadap Venezuela merupakan suatu tindakan pelanggaran menurut hukum internasional. Karena meskipun bertujuan untuk kemanusiaan dan hak asasi manusia, hal ini tidak dapat dibenarkan jika sudah memasuki ranah politik suatu negara didalam mempengaruhi integritas kedaulatan suatu negara, dalam hal ini Venezuela. Karena menurut International Court of J ustice tindakan intervensi militer sama dengan tindakan yang menggunakan kekerasan bersenjata, apalagi terhadap kudeta merupakan suatu tindakan pelanggaran hak asasi manusia.

\section{DAFTAR PUSTAKA}

\section{JURNAL}

Acemoglu, Daron., Ticchi, Davide., \& Vindigni, Andrea. (2010). A Theory of Military Dictactorships. American Economi Journal: Macroeconomics, Vol.2, (No.1), pp.1-42.

Criddle, Evan J., \& Decent, Evan Fox. (2009). A Fiduciary Theory of Jus Cogens. Yale J ournal of International, Vol.34, Issue 2, pp.331-387.

Dimyati, Khudzaifah., Muqoddas, Mohammad Busjro., \& Wardiono, Kelik. (2013). Radikalisme Islam dan Peradilan: Pola-pola Intervensi Kekuasaan dalam Kasus Komando Jihad di
Indonesia. Jurnal Dinamika Hukum, Vol.13, (No.3), pp.379-391.

Eliza, Emi., Heryandi, \& Syofyan, Ahmad. (2014). Intervensi Kemanusiaan (Humanitarian Intervention) Menurut Hukum Internasional dan Implementasinya Dalam Konflik Bersenjata. Fiat J ustisia : Jurnal IImu Hukum, Vol.8, (No.4), pp.629-641.

Erliyana, A. (2006). Penegakan Rasa Aman Melalui Intervensi Kemanusiaan. Indonesia J ournal of International Law, Vol.3, (No.3), pp.404-411.

Hendra, E. (2014). Sekuritisasi dalam kerangka "R2P" dan Intervensi Kemanusiaan: Dilema Antara Legalitas dan Legitimasi. Jurnal Hubungan Internasional, Vol.3,(No.2), pp.131141.

Indrawan, J. (2013). Legalitas dan Motivasi NATO (North Atlantic Treaty Organization) dalam Melakukan Intervensi Kemanusiaan di Libya. Jurnal Kajian Wilayah, Vol.4, (No.2), pp.127149.

Latifulhayat, A. (2004). Perang Irak dan Hukum Internasional. Unpad J ournal of International Law, Vol.3, (No.2), pp.70-86.

Muhammadin, Fajri M. (2018). Humanitarian Intervention and The Jus Cogens Argument : A Critical Observation. Padjajaran Jurnal IImu Hukum;J ournal of Law, Vol.5, (No.1), pp.71-88. Murtadlo, H. (2014). Intervensi Militer Perancis di Mali : Sekularisme vs Fundamentalisme Islam. J urnal Hubungan Internasional, Vol.7,(No.2), pp.139-152. 
Priyono, J. (2011). Intervensi Kemanusiaan Dalam Perspektif Pemikiran Kosmopolit. MasalahMasalah Hukum, Vol.40, (No.3), pp.325-331.

Putri, Lili H. (2015). Responsibility to Protect Sebagai Doktrin Atau Norma Yang Berkembang Dalam Hukum Internasional. Kanun Jurnal IImu Hukum, Vol.17, (No.1), pp.151-171.

Rosyidin, M. (2016). Intervensi Kemanusiaan Dalam

Studi Hubungan Internasional: Perdebatan Realis Versus Konstruktivis. Global \& Strategis, Vol.10, (No.1), pp.55-73.

Roth, K. (2006). Was the Iraq War a Humanitarian Intervention?. J ournal of Military Ethics, Vol.5, (No.1), pp.84-92.

Saraswati, AAA Nanda. (2017). Kriteria untuk Menentukan Hak Asasi Manusia Sebagai "Jus Cogens" Dalam Hukum Internasional. Arena Hukum, Vol.10(No.2), pp.163-184.

Setiawan, A. (20015). Diplomatic Dilemma dan Standar Ganda Politik Amerika Serikat Terhadap Konflik Sipil-Militer Mesir Tahun 2013. Jurnal Hubungan Internasional, Vol.4, (No.1), pp.67-77.

Suryokusumo, S. (2003). Ancaman Kekuatan Militer

Dari Luar Menurut Perspektif Hukum Internasional. Jurnal Ketahanan Nasional, Vol.8, (No.1), pp.71-76.

Yuniasih, Tulus., Rizky, Riasa., \& Natasha, Claudia. (2016). Dinamika Penegakan Hukum Humaniter Internasional : Analisis Kehadiran PMSC Dalam Konflik Non-Internasional. Jurnal Hubungan Internasional, Vol.5,(No.2), pp.222-237.
Zainal, Nur A. (2013). Hubungan Sipil-Militer di Chile Pasce Augusto Pinochet, 1990-2000. Jurnal Politik Profetik, Vol.1, (No.1), pp.1-13.

\section{BUKU}

Starke, J. G. (2012). Pengantar Hukum Internasional (Edisi Kesepuluh). Jakarta: Sinar Grafika.

\section{SUMBER ONLINE}

Eniayejuni, Anthony T. (2012). The Role of The West and Military Intervention in Libya. Foreign Policy Journal, (April 7, 2012). Retrieved from https://www.foreignpolicyjournal.com/2012/04/0 7/the-role-of-the-west-and-military-interventionin-libyal

Aninda, N. (2019). Krisis Kepemimpinan Venezuela Masuki Babak Baru. Retrieved from https://kabar24.bisnis.com/read/20190505/19/9 18829/krisis-kepemimpinan-venezuela-masukibabak-baru

Aipassa, J. (2019). 10 Negara Dukung Kepemimpinan Guaido. Retrieved from https://www.beritasatu.com/dunia/535003/10negara-dukung-kepemimpinan-guaido

Sukarno, A. (2019). Rusia Kecam Intervensi Asing di Venezuela, Trump Amankan Warganya. Retrieved from https //indopos.co.id/read/2019/01/25/163209/rusiakecam-intervensi-asing-di-venezuela-trumpamankan-warganya/

Nursalikah, A. (2019a). AS Serius Pertimbangkan Inervensi Militer di Venezuela. Retrieved from 
Jurnal Pembangunan Hukum Indonesia

Volume 1, Nomor 3, Tahun 2019

https://internasional.republika.co.id/berita/intern

asional/amerika/ppiz0q366/as-serius-

pertimbangkan-intervensi-militer-di-venezuela

Nursalikah, A. (2019b). Uni Eropa Tolak Intervensi

Militer di Venezuela. Retrieved from

https://www.republika.co.id/berita/internasional/

amerika/19/03/13/poabdh366-uni-eropa-tolak-

intervensi-militer-di-venezuela
Program Studi Magister Ilmu Hukum Fakultas Hukum Universitas Diponegoro 